\title{
Effects of genetic variants in milk protein on yield and composition of milk from Holstein-Friesian and Simmentaler cows
}

\author{
A.D. Çardak \\ Department of Food Science and Technology, Agricultural Faculty of Adnan Menderes University, Aydin, Turkey
}

\begin{abstract}
Milk samples from 237 Holstein-Friesian (HF) and 177 Simmentaler cows in six herds were typed for genetic variants of $\alpha_{\mathrm{S}_{1}}, \beta$ - and $\kappa$-caseins $(\mathrm{Cn})$ and $\beta$-lactoglobulin $(-\mathrm{Lg})$ using ultrathin-layer polyacrylamide isoelectric focusing in the presence of carrier ampholytes $(3-10 \mathrm{pH})$. The frequency distribution of genetic variants of all four milk protein systems was different in HF and Simmentaler. In addition, milk production traits of the dairy cows were compared according to the genetic variants of each milk protein fraction. Milk yield was significantly influenced by $\kappa-\mathrm{Cn}$ (genotype $\mathrm{AA}>$ genotype $\mathrm{AB}$ ) and $\beta-\mathrm{Lg}(\mathrm{AB}>\mathrm{BB}>\mathrm{AA})$ in $\mathrm{HF}$, while in the Simmentaler milk yield was significantly associated with $\beta-C n$ $\left(A^{2} A^{2}>A^{1} B>A^{2} B>A^{1} A^{2}>A^{1} A^{1}\right)$ and $\kappa-C n(A B>A A>B B)$. In terms of protein content $\alpha_{S_{1}-C n}$ was significant $(B C>B B)$ in $H F$, and $\alpha_{S 1}-C n(B C>B B), \beta-C n\left(A^{1} A^{1}>A^{2} A^{2}>A^{1} B>A^{1} A^{2}>A^{2} B\right), \kappa-C n$ $(\mathrm{AA}>\mathrm{AB}=\mathrm{BB})$ as well as $\beta-\mathrm{Lg}(\mathrm{BB}>\mathrm{AA}>\mathrm{AB})$ were significant in Simmentaler. The effects of milk protein genetic variants on milk fat content in HF were not significant, while in Simmentaler this trait was significantly affected by $\alpha_{S 1}-C n(B C>B B), \quad \beta-C n\left(A^{1} A^{1}>A^{1} B>A^{2} A^{2}>A^{1} A^{2}>A^{2} B\right)$ and $\beta-L g$ $(\mathrm{BB}>\mathrm{AA}>\mathrm{AB})$.
\end{abstract}

Keywords: $\alpha_{\mathrm{S1}}$-casein, $\beta$-casein, $\kappa$-casein, $\beta$-lactoglobulin, isoelectric focusing (IEF), polyacrylamide gel E-mail: adcardak@hotmail.com; adenizcardak@yahoo.de

\section{Introduction}

In bovine milk, six major milk protein fractions $\left(\alpha_{S_{1}}\right.$-casein, $\alpha_{S_{2}}$-casein, $\beta$-casein, $\kappa$-casein, $\alpha$-lactalbumin, $\beta$-lactoglobulin), which are controlled by codominant autosomal genes according to Mendelian inheritance exist in different allelic forms. Since the initial discovery of polymorphism of the whey protein, $\beta$-lactoglobulin (-Lg) and a quantitative distribution of its variants (Aschaffenburg \& Drewry, 1955 ; 1957) researchers have become interested in the genetic polymorphism of milk proteins. It is known today that there are at least 39 genetic variants of six milk protein fractions (Eigel et al., 1984; Bouniol et al., 1993; Miranda et al., 1993; Mariani et al., 1995; Visser et al., 1995; Godovac-Zimmermann et al., 1996; Prinzenberg et al., 1996; 1998; Han et al., 2000). These genetic variants occur as a consequence of either substitution or deletion of amino acids within the polypeptide chain (Eigel et al., 1984). The four caseins are encoded by four clustered autosomal genes localized on chromosome 6 , in the order $\alpha_{\mathrm{S}^{-}}, \beta-, \alpha_{\mathrm{S}^{-}}$and $\kappa-$ casein (-Cn) (Threadgill \& Womack, 1990; Rijnkels et al., 1997) while the $\alpha$-lactalbumin (-La) gene is on chromosome 5 (Eggen \& Fries, 1995) and the $\beta$-lactoglobulin (-Lg) gene is on chromosome 11 (Vaiman et al., 1994).

In the past 20 years researchers from different countries have indicated that there are possible associations between certain genetic variants of milk protein and production traits, milk composition and overall manufacturing properties of milk (see reviews by Jakob \& Puhan, 1992 and Ng-Kwai-Hang \& Grosclaude, 1992). An association of milk protein genotype with milk composition and properties of milk could be exploited commercially by using these genotypes as an additional criterion in selecting bulls for artificial insemination. For example, increasing the frequency of a milk protein genotype associated with increased milk yield and protein concentration would increase cheese yields. Therefore, these findings have raised the interest among research groups around the world because of the potential of using milk protein genes as markers to aid in the selection for milk yield and quality.

The objective of the present study was to determine the milk protein polymorphism of HolsteinFriesian (HF) and Simmentaler breeds and to evaluate the effects of composite milk protein genotypes on the milk production traits as well as protein and fat percentages of milk. 


\section{Materials and Methods}

Records of 237 Holstein-Friesian and 177 Simmentaler cows from registered dairy herds in SouthWest Germany were used in this study. The records included data related to each milk sample such as the date of milking, somatic cell count, daily milk yield, protein and fat concentrations as well as the age of the cow and stage of lactation. Milk samples were collected monthly from six herds. Individual milk samples (10 $\mathrm{mL}$ ), which were preserved with sodium-acid $\left(\mathrm{NaN}_{3}\right)$, were centrifuged for $10 \mathrm{~min}$ at $4550 \mathrm{G}$ at $4{ }^{\circ} \mathrm{C}$. The skim milk phase was partitioned and stored at $-80^{\circ} \mathrm{C}$.

The fat and protein concentrations of the milk were analyzed by the infrared method and the Fossomatic cell counter was used to determine the somatic cell count in the milk. The phenotyping of skim milk samples was carried out by isoelectric focusing (IEF) in $0.5 \mathrm{~mm}$ polyacrylamide gels $(114 \mathrm{x} 248 \mathrm{~mm})$, using carrier ampholytes ( $\mathrm{pH} 3.0-10.0)$ according to the method reported by Seibert et al. (1985) and Erhardt (1989). For the preparation of the gel solution $3.1 \mathrm{~mL}$ acrylamide stock solution $(30 \% \mathrm{~T}$ and $3 \% \mathrm{C}), 2 \mathrm{~mL}$ glycerin, $520 \mu \mathrm{L}$ Pharmalyte ${ }^{\circledR}\left(\mathrm{pH}\right.$ 4.2-4.9), $130 \mu \mathrm{L}$ Ampholine ${ }^{\circledR}(\mathrm{pH}$ 4.0-6.0) (LKB Pharmacia, Freiburg, Germany), $260 \mu \mathrm{L}$ Servalyte ${ }^{\circledR}(\mathrm{pH} 3.0-10.0), 130 \mu \mathrm{L}$ Servalyte ${ }^{\circledR}$ (pH 5.0-7.0) (Serva, Heidelberg, Germany) and $13.86 \mathrm{~mL}$ urea $(11.53 \mathrm{M})$ were mixed. After degassing of the gel solution for about $5 \mathrm{~min}$ at room temperature, $10 \mu \mathrm{L}$ TEMED and $100 \mu \mathrm{L}$ APS $(10 \% \mathrm{w} / \mathrm{w})$ were added. Skim milk samples $(10 \mu \mathrm{L})$ were diluted with a $50 \mu \mathrm{L}$ sample preparation solution containing $8 \mathrm{M}$ urea and $0.2 \%(\mathrm{v} / \mathrm{v}) 2$-mercaptoethanol, and shaken for $1 \mathrm{~h}$ at room temperature. For isoelectric focusing $1 \mathrm{M} \mathrm{H}_{3} \mathrm{PO}_{4}$ anode and $1 \mathrm{M} \mathrm{NaOH}$ cathode solutions were prepared. After pre-focusing at a $2000 \mathrm{~V}$ limit and $20 \mathrm{~mA}$ constant current for $350 \mathrm{Vh}$ at $9{ }^{\circ} \mathrm{C}$, $5 \mu \mathrm{L}$ of each milk sample was injected into the gel at a distance of $1 \mathrm{~cm}$ from the anode. Focusing was carried out up to $3500 \mathrm{Vh}$ under the same conditions and final focusing at $2500 \mathrm{~V}$ for $500 \mathrm{Vh}$. The genetic variants were identified after staining with a solution containing $0.08 \%(\mathrm{w} / \mathrm{v})$ Coomassie Brilliant Blue G$250,40 \mathrm{mM} \mathrm{H}_{2} \mathrm{SO}_{4}, 8.7 \%(\mathrm{v} / \mathrm{v}) 10 \mathrm{~N} \mathrm{NaOH}$ and $12.25 \%(\mathrm{v} / \mathrm{v})$ trichloracetic acid (100\%).

To study the relationship between genetic variants of $\alpha_{\mathrm{S1}^{-}}, \beta$ - and $\kappa$-casein $(\mathrm{Cn})$ as well as $\beta$ - $\mathrm{Lg}$ and milk production traits and milk composition, a least squares analysis of variance was carried out using the General Linear Model (GLM) procedure of SAS (1993). The model fitted included genetic variant of milk protein encoding gene, herd-breed combination, stage of lactation, parity number, season and cow. Somatic cell count (SCC) was included as a linear-quadratic covariate in this model. There were three, five, eight and five subclasses for the effects of season, parity number, stage of lactation and SCC, respectively. The $\chi^{2}$-test was carried out to determine whether the observed genotype frequencies deviated significantly from the Hardy-Weinberg-Equilibrium.

\section{Results and Discussion}

The distribution of genotypes for milk proteins obtained by isoelectric focusing (IEF) in polyacrylamide gel in the milk of HF and Simmentaler cows is summarized in Table 1. The genotypes were recorded directly from the codominant patterns of milk proteins. The results obtained from the study showed that polymorphism exists in both breeds for $\alpha_{\mathrm{SI}_{1}} \mathrm{Cn}, \beta-\mathrm{Cn}, \kappa-\mathrm{Cn}$ and $\beta-\mathrm{Lg}$. The AA and BB genotypes were observed for $\alpha_{\mathrm{S} 2}-\mathrm{Cn}$ and $\alpha$-La, respectively. In Simmentaler cows there was no significant difference (P > 0.05) between observed frequencies and those estimated from the Hardy-Weinberg-Equilibrium. On the other hand, in HF cows the observed genotype frequencies for $\beta$-Cn and $\kappa$-Cn differed significantly from the estimated ones. Although according to estimations, approximately $17 \mathrm{HF}$ cows were expected to carry the $\kappa$ Cn BB genotype, it was observed that only three cows possessed this genotype. Bösze \& Dohy (1993) reported similar results and they suggested that the deviation could be due to crossbreeding with HF sires from the United States.

The allele frequencies are presented in Table 2. The frequency of allele $\mathrm{B}$ at $\alpha_{\mathrm{S}_{1}}-\mathrm{Cn}$ was the highest in both breeds. At $\beta$-Cn the alleles $\mathrm{A}^{1}$ and $\mathrm{A}^{2}$ appeared most frequently. In HF the frequency of allele $\mathrm{A}^{2}$ was 2.3 times higher than that of $\mathrm{A}^{1}$, while in the Simmentaler the frequencies of these alleles were nearly equal. In both breeds the allele A of $\kappa-\mathrm{Cn}$ occurred most frequently, while in the Simmentaler and HF cows the frequency of allele A was ca. 2- and 2.7-times higher than that of allele B, respectively. At $\beta$-Lg there were mainly two alleles in which the frequency levels were equal for the Simmentaler cows, while in the HF cows the frequency of allele B was ca. 1.6-times higher than that of allele A. 
Table 1 Genotype distributions of $\alpha_{\mathrm{S}^{-}}, \beta-$, -casein (-Cn) and $\beta$-lactoglobulin for the Holstein-Friesian and Simmentaler cows

\begin{tabular}{|c|c|c|c|c|c|c|c|c|c|}
\hline \multirow[t]{3}{*}{ Locus } & \multirow[t]{3}{*}{ Genotype } & \multirow{2}{*}{\multicolumn{4}{|c|}{$\begin{array}{l}\text { Holstein- Friesian } \\
\qquad N=237\end{array}$}} & \multirow{2}{*}{\multicolumn{4}{|c|}{$\begin{array}{c}\text { Simmentaler } \\
\mathrm{N}=177\end{array}$}} \\
\hline & & & & & & & & & \\
\hline & & Observed & Expected $^{1)}$ & $\%$ & $\mathrm{P}^{2)}$ & Observed & Expected $^{1)}$ & $\%$ & $\mathrm{P}^{2)}$ \\
\hline \multirow[t]{3}{*}{$\alpha_{\mathrm{S} 1}-\mathrm{Cn}$} & $\mathrm{BB}$ & 228 & 228.1 & 96.2 & & 154 & 153.8 & 87.0 & \\
\hline & $\mathrm{BC}$ & 9 & 8.8 & 3.8 & & 22 & 22.4 & 12.4 & \\
\hline & $\mathrm{CC}$ & 0 & 0.1 & 0 & & 1 & 0.8 & 0.6 & \\
\hline & & & & & n.s. & & & & n.s. \\
\hline \multirow[t]{14}{*}{$\beta-\mathrm{Cn}$} & $\mathrm{A}^{1} \mathrm{~A}^{1}$ & 14 & 20.6 & 5.9 & & 25 & 26.4 & 14.1 & \\
\hline & $\mathrm{A}^{1} \mathrm{~A}^{2}$ & 109 & 93.6 & 46.0 & & 68 & 63.6 & 38.4 & \\
\hline & $A^{1} A^{3}$ & 0 & 0.9 & 0 & & 1 & 1.2 & 0.6 & \\
\hline & $\mathrm{A}^{1} \mathrm{~B}$ & 3 & 4.4 & 1.3 & & 15 & 16.3 & 8.5 & \\
\hline & $\mathrm{A}^{1} \mathrm{C}$ & 0 & 0 & 0 & & 3 & 3.1 & 1.7 & \\
\hline & $A^{2} A^{2}$ & 97 & 105.2 & 40.9 & & 33 & 37.9 & 18.6 & \\
\hline & $A^{2} A^{3}$ & 2 & 2.0 & 0.8 & & 2 & 1.4 & 1.1 & \\
\hline & $\mathrm{A}^{2} \mathrm{~B}$ & 11 & 10.0 & 4.6 & & 23 & 19.3 & 13.0 & \\
\hline & $\mathrm{A}^{2} \mathrm{C}$ & 0 & 0 & 0 & & 5 & 3.7 & 2.8 & \\
\hline & $A^{3} B$ & 1 & 0.1 & 0.4 & & 0 & 0.4 & 0 & \\
\hline & BB & 0 & 0.2 & 0 & & 2 & 2.4 & 1.1 & \\
\hline & $\mathrm{BC}$ & 0 & 0 & 0 & & 0 & 1.0 & 0 & \\
\hline & $\mathrm{CC}$ & 0 & 0 & 0 & & 0 & 0.1 & 0 & \\
\hline & & & & & $*$ & & & & n.s. \\
\hline \multirow[t]{4}{*}{$\kappa-\mathrm{Cn}$} & $\mathrm{AA}$ & 113 & 126.9 & 47.7 & & 76 & 80.6 & 42.9 & \\
\hline & $\mathrm{AB}$ & 121 & 93.2 & 51.0 & & 87 & 77.8 & 49.2 & \\
\hline & BB & 3 & 16.9 & 1.3 & & 14 & 18.6 & 7.9 & \\
\hline & & & & & $* * *$ & & & & n.s. \\
\hline \multirow[t]{7}{*}{$\beta-\mathrm{Lg}$} & AA & 35 & 34.8 & 14.8 & & 46 & 43.1 & 26.0 & \\
\hline & $\mathrm{AB}$ & 112 & 112.4 & 47.2 & & 82 & 87.3 & 46.3 & \\
\hline & $\mathrm{AD}$ & 0 & 0 & 0 & & 1 & 1.5 & 0.6 & \\
\hline & BB & 90 & 89.9 & 38.0 & & 46 & 43.6 & 26.0 & \\
\hline & $\mathrm{BD}$ & 0 & 0 & 0 & & 2 & 1.5 & 1.1 & \\
\hline & DD & 0 & 0 & 0 & & 0 & 0 & 0 & \\
\hline & & & & & n.s. & & & & n.s. \\
\hline
\end{tabular}

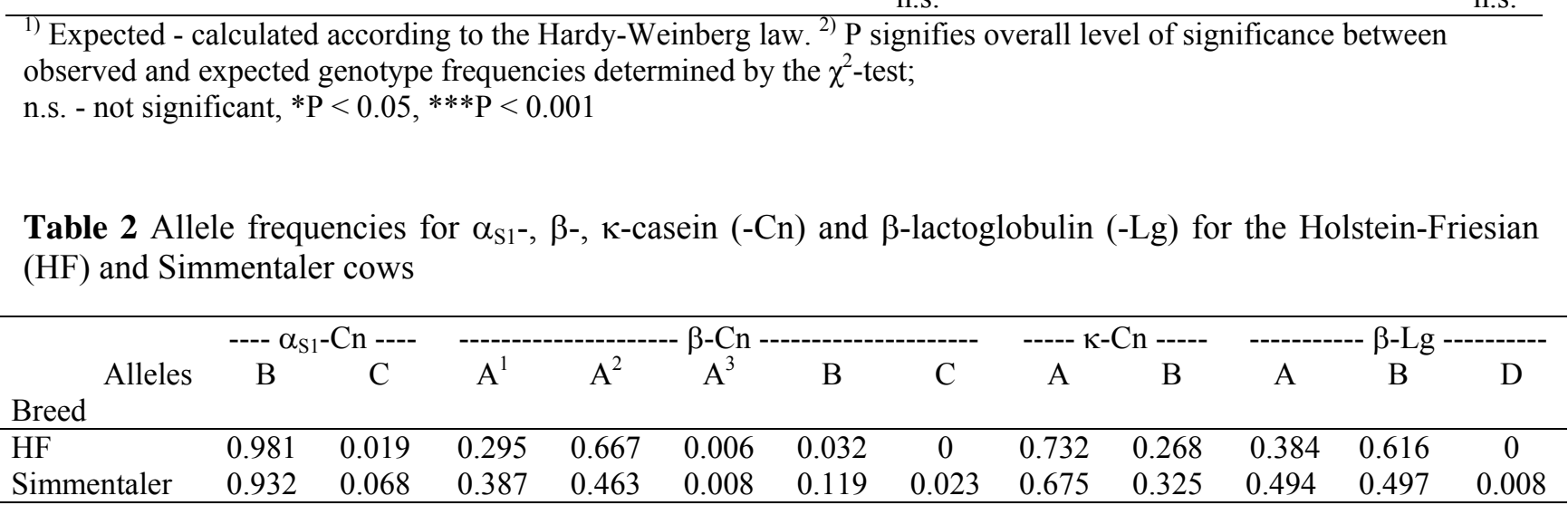

Comparing allele frequencies with other studies showed similar results. In HF cows the frequency of $\alpha_{\mathrm{S} 1}-\mathrm{Cn}$ B was similar to that found by Aleandri et al. (1990) and Panicke et al. (1996), and it was higher and lower, respectively, than the frequencies obtained by McLean et al. (1984) and Erhardt (1993). In this study the frequencies of $\beta-C n A^{1}$ were lower and $A^{2}$ higher than the results of McLean et al. (1984), Aleandri et al. (1990), Erhardt (1993) Panicke et al. (1996), while the frequency of $\beta$-Cn B was similar to the findings of some authors (McLean et al., 1984; Aleandri et al., 1990; Erhardt, 1993). At $\kappa-\mathrm{Cn}$, the frequency of allele A 
was in agreement with the results of Aleandri et al. (1990), while it was lower than the results of other researchers (Erhardt, 1993; Bobe et al., 1999) and higher than reported by McLean et al. (1984). The frequencies of $\beta-\mathrm{Lg}$ A and B were nearly similar to the findings of Panicke et al. (1996) and McLean et al. (1984), but were lower than that reported by Erhardt (1993) and higher than the results of Bobe et al. (1999). For Simmentaler cows the frequency of $\alpha_{\mathrm{S}_{1}}-\mathrm{Cn} \mathrm{B}$ was higher and that of $\alpha_{\mathrm{S} 1}-\mathrm{Cn} \mathrm{C}$ lower than the results of Graml et al. (1984), Putz et al. (1991), Erhardt (1993), Ortner et al. (1995) and Falaki et al. (1997). The frequencies of $\beta-C n A^{1}$ and $B$ were higher and that of allele $\mathrm{A}^{2}$ lower than the frequencies reported by other researchers (Putz et al., 1991; Erhardt, 1993; Ortner et al., 1995). The $\beta$-Cn C was less frequent than the values reported by Graml et al. (1984) and more frequent than that of Putz et al. (1991), Erhardt (1993), Ortner et al. (1995) and Falaki et al. (1997). The frequencies of $\kappa-C n$ A and B were similar to that of Graml et al. (1984) and Ortner et al. (1995), while the frequency of $\kappa-\mathrm{Cn}$ A was higher than that of Putz et al. (1991) and lower than that of Erhardt (1993) and Falaki et al. (1997). The frequencies of $\beta$-Lg A and B were equal, in agreement with the findings of Graml et al. (1984) and Putz et al. (1991). The frequency of $\beta-\mathrm{Lg} B$ was higher than that reported by Erhardt (1993) and Falaki et al. (1997) and lower than the result of Ortner et al. (1995).

Least square means and standard errors of test-day milk, protein and fat yields, protein and fat percentages for the different genetic variants $\alpha_{\mathrm{S}_{1}}$, $\beta$ - and $\kappa-\mathrm{Cn}$ and $\beta$-Lg are presented in Table 3. It was found that in both breeds milk protein levels were affected $(\mathrm{P}<0.001)$ by $\alpha_{\mathrm{S} 1}-\mathrm{Cn}$, while this locus had no effect $(\mathrm{P}>0.05)$ on daily milk, protein and fat yields and fat concentration in HF cows. In Simmentaler cows the daily milk, protein and fat yields were not affected $(\mathrm{P}>0.05)$ by $\alpha_{\mathrm{S} 1}-\mathrm{Cn}$, while fat concentration was affected $(\mathrm{P}<0.05)$. Compared to genotype BB, both the HF and Simmentaler cows with BC at the $\alpha_{\mathrm{S}_{1}-\mathrm{Cn}}$ locus had a $3.6 \%$ higher protein content in their milk. This result is supported by other researchers (Aleandri et al., 1990; Bovenhuis et al., 1992; Mao et al., 1992; Ortner et al., 1995; Lodes et al., 1997).

In Simmentaler cows the genetic variants of $\beta$-Cn were associated with a higher $(\mathrm{P}<0.001)$ milk yield, protein yield and protein concentration. Fat concentration was affected $(\mathrm{P}<0.05)$ by the genetic variants of $\beta$-Cn, while fat yield was not affected $(\mathrm{P}>0.05)$. In $\mathrm{HF}$ cows the $\beta$-Cn genetic variants showed no effect $(\mathrm{P}>0.05)$ on the daily milk and protein yields or on protein and fat content, while only fat yield was affected $(\mathrm{P}<0.05)$ by genetic variants of $\beta-\mathrm{Cn}$. The HF cows possessing $\beta-\mathrm{Cn} \mathrm{A}^{1} \mathrm{~A}^{1}$ genotype had $130 \mathrm{~g}$ more testday milk fat than the cows with the $\beta-C n A^{2} B$ genotype. In Simmentaler cows the daily milk, milk protein and milk fat yields of cows possessing the $\beta-\mathrm{Cn} \mathrm{A}^{2} \mathrm{~A}^{2}$ genotype were $4050 \mathrm{~g}, 130 \mathrm{~g}$ and $120 \mathrm{~g}$ higher than that of cows with the $\mathrm{A}^{1} \mathrm{~A}^{1}$ genotype, respectively, while the cows with the $\beta-\mathrm{Cn} \mathrm{A}^{1} \mathrm{~A}^{1}$ genotype had $9.8 \%$ and $11 \%$ higher protein and fat concentrations in their milk, respectively, than cows possessing the $\mathrm{A}^{2} \mathrm{~B}$ genotype. Bech \& Kristiansen (1990) also found that the $\mathrm{A}^{2} \mathrm{~A}^{2}$ genotype of $\beta$-Cn was favourable for milk, protein and fat yields. Ortner et al. (1995) showed that Simmentaler cows possessing $\beta-C n A^{1} A^{1}$ had significantly higher protein and fat levels in their milk than the other genotypes.

The results of this study showed that daily milk, protein and fat yields were affected by the genotypes of $\kappa-\mathrm{Cn}(\mathrm{P}<0.001)$ in HF cows, while in Simmentaler cows the $\kappa-\mathrm{Cn}$ genotypes had an effect on protein content $(\mathrm{P}<0.001)$ and daily fat yield $(\mathrm{P}<0.01)$. The HF cows with $\kappa-\mathrm{Cn}$ AA produced respectively $1560 \mathrm{~g}$, $50 \mathrm{~g}$ and $80 \mathrm{~g}$ more daily milk, protein and fat than the other genotypes. Simmentaler cows possessing the $\mathrm{K}-$ $\mathrm{Cn}$ AA genotype produced $2 \%$ more protein as well as $60 \mathrm{~g}$ and $100 \mathrm{~g}$ more protein and fat per day, respectively, than the cows with the $\mathrm{BB}$ genotype. The cows possessing the $\mathrm{AB}$ genotype at the $\kappa$-Cn locus produced $1390 \mathrm{~g}$ more milk on test-day than the other genotypes. The results for milk and fat yield of HF cows were in agreement with that of Bovenhuis et al. (1992).

In the HF cows the genotypes, $\beta-\mathrm{Lg}$, had an effect $(\mathrm{P}<0.01)$ on daily milk, protein and fat yields, while in Simmentaler cows fat concentration was affected by the $\beta-\operatorname{Lg}$ genotypes $(\mathrm{P}<0.01)$. It was found that the daily milk, protein and fat yields of HF cows with the $\beta$ - $\mathrm{Lg}$ AB genotype were $2170 \mathrm{~g}, 70 \mathrm{~g}$ and 100 $\mathrm{g}$ higher than that of cows possessing the $\beta$-Lg AA genotype. Simmentaler cows possessing $\beta$ - Lg AB had $2170 \mathrm{~g}$ more milk on test-day than that of $\beta$ - $\mathrm{Lg}$ AA cows. In addition, $\beta$ - $\mathrm{Lg}$ AA cows produced $40 \mathrm{~g}$ more daily milk protein than cows with the $\beta$-Lg BB genotype, while the $\beta$ - $\operatorname{Lg}$ BB genotype showed $2 \%$ and $4 \%$ more protein and fat levels than that of cows of the $\beta-\mathrm{Lg} \mathrm{AB}$ genotype. The results are in agreement with those reported by McLean et al. (1984), Bovenhuis et al. (1992), Mao et al. (1992), Falaki et al. (1997). 
Table 3 Associations between milk protein genetic variants and test-day milk yield, protein and fat yields, and protein and fat content in Holstein-Friesian and Simmentaler cows (LS-Means \pm s.e.)

\begin{tabular}{|c|c|c|c|c|c|c|c|c|}
\hline \multirow[t]{2}{*}{ Locus $^{1)}$} & \multirow[t]{2}{*}{ Genotype $^{2)}$} & \multirow{2}{*}{\multicolumn{2}{|c|}{ Number of }} & \multirow{2}{*}{$\begin{array}{l}\text { Milk yield } \\
\text { (kg/day) }\end{array}$} & \multicolumn{2}{|c|}{ Milk protein } & \multicolumn{2}{|c|}{ Milk fat } \\
\hline & & & & & $(\%)$ & (kg/day) & $(\%)$ & (kg/day) \\
\hline \multicolumn{9}{|c|}{ Holstein-Friesian } \\
\hline \multirow[t]{3}{*}{$\alpha_{\mathrm{S} 1}-\mathrm{Cn}$} & $\mathrm{BB}$ & 1155 & 228 & $28.53 \pm 0.42$ & $3.31^{\mathrm{a}} \pm 0.02$ & $0.94 \pm 0.01$ & $4.22 \pm 0.02$ & $1.21 \pm 0.02$ \\
\hline & $\mathrm{BC}$ & 38 & 9 & $27.69 \pm 1.05$ & $3.43^{b} \pm 0.05$ & $0.95 \pm 0.03$ & $4.31 \pm 0.07$ & $1.22 \pm 0.05$ \\
\hline & & $\mathrm{P}^{3)}$ & & n.s. & & n.s. & n.s. & n.s. \\
\hline \multirow[t]{5}{*}{$\beta-\mathrm{Cn}$} & $\mathrm{A}^{1} \mathrm{~A}^{1}$ & 68 & 14 & $28.94 \pm 0.74$ & $3.35 \pm 0.03$ & $0.96 \pm 0.02$ & $4.47^{\mathrm{a}} \pm 0.05$ & $1.27^{\mathrm{a}} \pm 0.03$ \\
\hline & $\mathrm{A}^{1} \mathrm{~A}^{2}$ & 547 & 109 & $28.59 \pm 0.46$ & $3.30 \pm 0.02$ & $0.94 \pm 0.01$ & $4.20^{\mathrm{b}} \pm 0.02$ & $1.21 \pm 0.02$ \\
\hline & $A^{2} A^{2}$ & 491 & 97 & $28.68 \pm 0.50$ & $3.31 \pm 0.02$ & $0.94 \pm 0.02$ & $4.23^{b} \pm 0.05$ & $1.22 \pm 0.02$ \\
\hline & $A^{2} B$ & 58 & 11 & $27.29 \pm 0.67$ & $3.32 \pm 0.03$ & $0.90 \pm 0.02$ & $4.13^{b} \pm 0.05$ & $1.14^{\mathrm{b}} \pm 0.03$ \\
\hline & & $\mathrm{P}^{3)}$ & & n.s. & n.s. & n.s. & n.s. & \\
\hline \multirow[t]{2}{*}{$\kappa-\mathrm{Cn}$} & AA & 581 & 113 & $29.18^{\mathrm{a}} \pm 0.56$ & $3.31 \pm 0.02$ & $0.96^{\mathrm{a}} \pm 0.02$ & $4.25 \pm 0.04$ & $1.25^{\mathrm{a}} \pm 0.03$ \\
\hline & $\mathrm{AB}$ & $\mathrm{P}^{3)} 597$ & 121 & $\begin{aligned} 27.62^{\mathrm{b}} & \pm 0.31 \\
& * * *\end{aligned}$ & $\begin{array}{l}3.32 \pm 0.01 \\
\text { n.s. }\end{array}$ & $\begin{array}{c}0.91^{\mathrm{b}} \pm 0.01 \\
* * *\end{array}$ & $\begin{array}{c}4.22 \pm 0.02 \\
\text { n.s. }\end{array}$ & $\begin{array}{c}1.17^{\mathrm{b}} \pm 0.01 \\
* * *\end{array}$ \\
\hline \multirow[t]{4}{*}{$\beta-\operatorname{Lg}$} & AA & 175 & 35 & $26.89 \pm 0.45$ & $3.36 \pm 0.02$ & $0.89^{\mathrm{a}} \pm 0.01$ & $4.22 \pm 0.04$ & $1.13^{\mathrm{a}} \pm 0.02$ \\
\hline & $\mathrm{AB}$ & 550 & 112 & $29.06^{\mathrm{a}} \pm 0.52$ & $3.31 \pm 0.02$ & $0.96^{\mathrm{b}} \pm 0.02$ & $4.21 \pm 0.03$ & $1.23^{\mathrm{b}} \pm 0.02$ \\
\hline & $\mathrm{BB}$ & 468 & 90 & $28.10^{c} \pm 0.42$ & $3.32 \pm 0.02$ & $0.93^{\mathrm{a}} \pm 0.01$ & $4.26 \pm 0.03$ & $1.20^{\mathrm{b}} \pm 0.02$ \\
\hline & & $\mathrm{P}^{3)}$ & & $* *$ & n.s. & $* *$ & n.s. & \\
\hline \multicolumn{9}{|c|}{ Simmentaler } \\
\hline \multirow[t]{3}{*}{$\alpha_{\mathrm{S} 1}-\mathrm{Cn}$} & $\mathrm{BB}$ & 747 & 154 & $24.01 \pm 0.22$ & $3.54^{\mathrm{a}} \pm 0.01$ & $0.84 \pm$ & $4.12 \pm 0.03$ & 0.01 \\
\hline & $\mathrm{BC}$ & 100 & 22 & $22.66 \pm 0.68$ & $3.67^{b} \pm 0.04$ & $0.83 \pm 0.02$ & $4.15 \pm 0.09$ & $0.94 \pm 0.04$ \\
\hline & & $\mathrm{P}^{3)}$ & & n.s. & & n.s. & $*$ & n.s. \\
\hline \multirow[t]{6}{*}{$\beta-\mathrm{Cn}$} & $\mathrm{A}^{1} \mathrm{~A}^{1}$ & 124 & 25 & $21.36^{\mathrm{a}} \pm 0.41$ & $3.68^{\mathrm{a}} \pm 0.02$ & $0.77^{\mathrm{a}} \pm 0.01$ & $4.39^{a} \pm 0.06$ & $0.94^{\mathrm{a}} \pm 0.02$ \\
\hline & $\mathrm{A}^{1} \mathrm{~A}^{2}$ & 328 & 68 & $23.42^{b} \pm 0.29$ & $3.50^{\mathrm{b}} \pm 0.02$ & $0.81^{\mathrm{a}} \pm 0.01$ & $4.14^{\mathrm{b}} \pm 0.04$ & $0.97 \pm 0.02$ \\
\hline & $A^{1} B$ & 70 & 15 & $24.91^{\mathrm{bc}} \pm 0.61$ & $3.54^{b c} \pm 0.03$ & $0.87^{b c} \pm 0.02$ & $4.21 \pm 0.08$ & $1.04^{\mathrm{b}} \pm 0.03$ \\
\hline & $A^{2} A^{2}$ & 152 & 33 & $25.41^{\mathrm{c}} \pm 0.64$ & $3.63^{\mathrm{ac}} \pm 0.03$ & $0.90^{\mathrm{b}} \pm 0.02$ & $4.15 \pm 0.09$ & $1.06^{b} \pm 0.03$ \\
\hline & $A^{2} B$ & 115 & 23 & $24.07^{\mathrm{bc}} \pm 0.55$ & $3.35^{\mathrm{d}} \pm 0.03$ & $0.80^{\mathrm{ac}} \pm 0.02$ & $3.95^{\mathrm{b}} \pm 0.07$ & $0.95 \pm 0.03$ \\
\hline & & $\mathrm{P}^{3)}$ & & $* * *$ & $* * *$ & & $*$ & n.s. \\
\hline \multirow[t]{4}{*}{$\kappa-\mathrm{Cn}$} & AA & 364 & 76 & $24.25 \pm 0.41$ & $3.62^{\mathrm{a}} \pm 0.02$ & $0.86^{\mathrm{a}} \pm 0.01$ & $4.14 \pm 0.06$ & $1.00^{\mathrm{a}} \pm 0.02$ \\
\hline & $\mathrm{AB}$ & 421 & 87 & $24.30^{\mathrm{a}} \pm 0.25$ & $3.54^{\mathrm{b}} \pm 0.01$ & $0.85 \pm 0.01$ & $4.09 \pm 0.03$ & $0.99^{\mathrm{a}} \pm 0.01$ \\
\hline & $\mathrm{BB}$ & 66 & 14 & $22.91^{\mathrm{b}} \pm 0.49$ & $3.54 \pm 0.03$ & $0.80^{\mathrm{b}} \pm 0.02$ & $3.98 \pm 0.07$ & $0.90^{\mathrm{b}} \pm 0.03$ \\
\hline & & $\mathrm{P}^{3)}$ & & * & $* * *$ & $*$ & n.s. & $* *$ \\
\hline \multirow[t]{4}{*}{$\beta-\mathrm{Lg}$} & AA & 222 & 46 & $26.89 \pm 0.39$ & $3.55 \pm 0.02$ & $0.87^{\mathrm{a}} \pm 0.01$ & $4.15 \pm 0.05$ & $1.03 \pm 0.02$ \\
\hline & $\mathrm{AB}$ & 396 & 82 & $29.06^{\mathrm{a}} \pm 0.28$ & $3.52^{\mathrm{a}} \pm 0.02$ & $0.84 \pm 0.01$ & $4.07^{\mathrm{a}} \pm 0.04$ & $0.98 \pm 0.02$ \\
\hline & BB & 217 & 46 & $28.10^{c} \pm 0.35$ & $3.60^{b} \pm 0.02$ & $0.83^{b} \pm 0.01$ & $4.25^{\mathrm{b}} \pm 0.05$ & $1.00 \pm 0.02$ \\
\hline & & $\mathrm{P}^{3)}$ & & n.s. & * & n.s. & $* *$ & n.s. \\
\hline
\end{tabular}

${ }^{1)} \alpha_{\mathrm{S} 1}$-casein, $\beta$-casein, $\kappa$-casein (-Cn) and $\beta$-lactoglobulin (-Lg), ${ }^{2)}$ Genotypes with $\leq 5$ cows are not given, ${ }^{3)} \mathrm{P}$ signifies overall level of significance between each locus and yield as well as compositional traits of milk (F-Test),

n.s. - not significant, $* \mathrm{P}<0.05, * * \mathrm{P}<0.01, * * * \mathrm{P}<0.001$. Means within columns for each milk protein locus with different superscripts differ at $\mathrm{P}<0.01$

\section{Conclusions}

This study demonstrated the possible association between genetic variants of milk protein loci and daily milk, protein and fat yields, and protein and fat content of milk. The results showed that daily milk, protein and fat yields are significantly affected by the genetic variants of $\kappa-\mathrm{Cn}$ and $\beta-\mathrm{Lg}$ in $\mathrm{HF}$ cows, while protein content was affected $(\mathrm{P}<0.05)$ by the $\alpha_{\mathrm{S}_{1}}-\mathrm{Cn}$ locus. However, in Simmentaler cows the genotypes $\alpha_{\mathrm{S} 1}-\mathrm{Cn}$ and $\beta-\mathrm{Lg}$ are significantly associated with protein and fat content, while $\beta-\mathrm{Cn}$ and $\kappa-\mathrm{Cn}$ have a significant effect on daily milk and protein yields as well as protein content. In addition, in Simmentaler cows, $\beta$-Cn and $\kappa-C n$ have a significant effect on fat content of milk and test-day fat yield, respectively. In both breeds the $\alpha_{\mathrm{S} 1}-\mathrm{Cn} \mathrm{BC}$ is desirable for the protein content of milk. In addition, in HF cows, the 
favourable genetic variants of milk proteins are: $\beta-C n A^{1} A^{1}$ for fat percent and yield, $\kappa-C n A A$ and $\beta-\operatorname{Lg} A B$ for daily milk yield as well as protein and fat content. In Simmentaler cows $\beta-C n A^{2} A^{2}, \kappa-C n A B$ and $\beta-L g$ $\mathrm{AA}$ are favourable for daily milk yield. The other desirable genetic variants of milk proteins are: $\beta-\mathrm{Cn} \mathrm{A}^{1} \mathrm{~A}^{1}$ for protein and fat content as well as $\beta-\mathrm{Cn} \mathrm{A}^{2} \mathrm{~A}^{2}$ for protein and fat yields; $\kappa-\mathrm{Cn} \mathrm{AA}$ for protein and fat content and milk fat yield; $\beta-\mathrm{Lg}$ AA for protein yield and $\beta$-Lg BB for protein and fat content. In this context, selection for above-mentioned genetic variants of milk protein loci would be more appropriate, due to the fact that milk from these cows is associated with higher content of protein and fat as well as a higher daily milk yield. However, because of close linkage between casein loci, attention should be paid to the effect of composite genotypes or haplotypes on milk yield and composition.

\section{Acknowledgements}

The author expresses her gratitude to Gülcin Mergen Cardak of The Middle East Technical University, Department of English for her kind help with the correction of the language.

\section{References}

Aleandri, R., Buttazzoni, L.G., Schneider, J.C., Caroli, A. \& Davoli, R., 1990. The effects of milk protein polymorphism on milk components and cheese-producing ability. J. Dairy Sci. 73, 241-255.

Aschaffenburg, R. \& Drewry, J., 1955. Occurrence of different $\beta$-lactoglobulins in cow's milk. Nature 176, 218-219.

Aschaffenburg, R. \& Drewry, J., 1957. Genetics of the $\beta$-lactoglobulins of cow's milk. Nature 180, 376-378.

Bech, A.M. \& Kristiansen, K.R., 1990. Milk protein polymorphism in Danish dairy cattle and the influence of genetic variants on milk yield. J. Dairy Res. 57, 53-62.

Bobe, G., Beitz, D.C., Freemen, A.E. \& Lindberg, G.L., 1999. Effect of milk protein genotypes on milk protein composition and its genetic parameter estimates. J. Dairy Sci. 82, 2797-2804.

Bouniol, C., Printz, C. \& Mercier, J.C., 1993. Bovine $\alpha$ S2-casein D is generated by exon VIII skipping. Gene 128, 289-293.

Bovenhuis, H., Arendonk, J.A.M. \& Korver, S., 1992. Associations between milk protein polymorphisms and milk production traits. J. Dairy Sci. 75, 2549-2559.

Bösze, Z. \& Dohy, J., 1993. Improvement of the quality of milk protein by new biotechnological methods. Hungarian Agricultural Research, 26-29.

Eggen, A. \& Fries, R., 1995. An integrated cytogenetic and meiotic map of the bovine genome. Anim. Genet. 26, 215-236.

Eigel, W.N., Butler, J.E., Ernstrom, C.A., Farrell, H.M., Harwalkar, V.R., Jenness, R. \& Whitney, R.McL., 1984. Nomenclature of proteins of cow's milk: fifth revision. J. Dairy Sci. 67, 1599-1631.

Erhardt, G., 1989. $\kappa-$ Kaseine in Rindermilchnachweis eines weiteren Allels $\left(\kappa-\mathrm{Cn}^{\mathrm{E}}\right)$ in verschiedenen Rassen. J. Anim. Breed. Genet. 106, 225-231.

Erhardt, G., 1993. Allele frequencies of milk proteins in German cattle breeds and demonstration of $\alpha_{\mathrm{S} 1}$-Casein variants by isoelectric focusing. Archiv für Tierzucht 63, 145-152.

Falaki, M., Prandi, A., Corradini, C., Sneyers, M., Gengler, N., Massart, S., Fazzini, U., Burny, A., Portetelle, D. \& Renaville, R., 1997. Relationships of growth hormone gene and milk protein polymorphisms to milk production traits in Simmentaler cattle. J. Dairy Sci. 64, 47-56.

Godovac-Zimmermann, J., Krause, I., Baranyi, M., Fischer-Frühholz, S., Juszczak, J., Erhardt, G., Buchberger, J. \& Klostermeyer, H., 1996. Isolation and rapid sequence characterisation of two novel bovine beta-lactoglobulins I and J. J. Protein Chem. 15, 743-750.

Graml, R., Buchberger, J., Kirchmeier, O., Kiermeier, F. \& Pirchner, F., 1984. Genfrequenzschätzung bei Milchproteinen des bayerischen Fleckviehs. Züchtungskunde 56, 73-87.

Han, S.K., Hin, Y.C. \& Byun, H.D., 2000. Biochemical, molecular and physiological characterization of a new $\beta$-casein variant detected in Korean cattle. Anim. Genet. 31, 49-51.

Jakob, E. \& Puhan, Z., 1992. Technological properties of milk as influenced by genetic polymorphism of milk proteins - A review. Int. Dairy J. 2, 157-178.

Lodes, A., Krause, I., Buchberger, J., Aumann, J. \& Klostermeyer, H., 1997. The influence of genetic variants of milk proteins on the compositional and technological properties of milk. 3. Content of protein, casein, whey protein and casein number. Milchwissenschaft 52, 3-8. 
Mao, I.L., Buttazzoni, L.G. \& Aleandri, R., 1992. Effects of polymorphic milk protein genes on milk yield and composition traits in Holstein cattle. Acta Agric. Scand. Anim. Sci. 42, 1-7.

Mariani, P., Summer, A., Anghinetti, A., Senese, C., Digregorio, P., Rando, A. \& Serventi, P., 1995. Effetidell'allele $\alpha_{S_{1}}$-Cn G sulla ripartizione percentuale delle caseine $\alpha_{S 1}, \alpha_{S 2}, \beta$ e $\kappa$ in vacche die razze Bruna. L'industria del latte 31, 3-13.

McLean, D.M., Graham, E.R.B., Ponzoni, R.W. \& McKenzie, H.A., 1984. Effects of milk protein genetic variants on milk yield and composition. J. Dairy Res. 51, 531-546.

Miranda, G., Anglade, P., Mahe, M.F. \& Erhardt, G., 1993. Biochemical characterization of the bovine genetic $\kappa$-Casein $\mathrm{C}$ and $\mathrm{E}$ variants. Anim. Genet. 24, 27-31.

Ng-Kwai-Hang, K.F. \& Grosclaude, F., 1992. Genetic polymorphisms of milk proteins. In: Advanced Dairy Chemistry, Vol. 1: Proteins. Ed. Fox, P.F., Elsevier Science Publishers, London. pp. 405-455.

Ortner, M., Essl, A. \& Sölkner, J., 1995. Zur züchterischen Bedeutung verschiedener MilchproteinGenotypen beim Rind. Züchtungskunde 67, 353-367.

Panicke, L., Freyer, G., Erhardt, G. \& Schlettwein, K., 1996. Milchproteingenotypen und ihr Einfluß auf die Milchleistungsmerkmale. Archiv für Tierzucht 39, 3-16.

Prinzenberg, E.M., Anglade, P., Ribadeau-Dumas, B. \& Erhartd, G., 1998. Biochemical characterization of bovine $\alpha_{S 1}$-casein $F$ and genotyping with sequence-specific primers. J. Dairy Res. 65, 223-231.

Prinzenberg, E.M., Hiendleder, S., Ikonen, T. \& Erhardt, G., 1996. Molecular genetic characterization of new bovine $\mathrm{K}$-casein alleles $\mathrm{CSN}_{3}{ }^{\mathrm{F}}$ and $\mathrm{CSN}_{3}{ }^{\mathrm{G}}$ and genotyping by PCR-RFLP. Anim. Genet. 27, 347-349.

Putz, M., Averdunk, G., Aumann, J. \& Buchberger, J., 1991. Genotypen für Milchprotein beim bayerischen Fleckvieh. Tierzüchter 43, 479-481.

Rijnkels, M., Kooiman, P.M., Boer, H.A. \& Pieper, F.R., 1997. Organization of the bovine casein gene locus. Mamm. Genome 8, 148-152.

SAS, 1993. Statistical Analysis Systems user's guide. (Version 6.1.2). SAS Institute Inc. Cary, NC, USA.

Seibert, B., Erhardt, G. \& Senft, B., 1985. Procedure for simultaneous phenotyping of genetic variants in cow's milk by isoelectric focusing. Animal Blood Groups and Biochemical Genetics 16, 183-191.

Threadgill, D.W. \& Womack, E., 1990. Genomic analysis of the major bovine milk protein genes. Nucl. Acids Res. 18, 6935-6942.

Vaiman, D., Mercier, D., Eggen, A., Bahri-Darwich, I., Grohs, C., Cribiu, E.P., Dolf, G., Ousrty, A., Guerin, G. \& Leveziel, H., 1994. A genetic and physical map of bovine Chromosome 11. Mamm. Genome 5, 553-556.

Visser, S., Slangen, C.J., Lagerwerf, F.M., Dongen, W.D. \& Haverkamp, J., 1995. Identification of a new genetic variant of bovine $\beta$-casein using reversed-phase high-performance liquid chromatography and mass spectrometric analysis. J. Chromatography A 711, 141-150. 